Jusmal lemiah
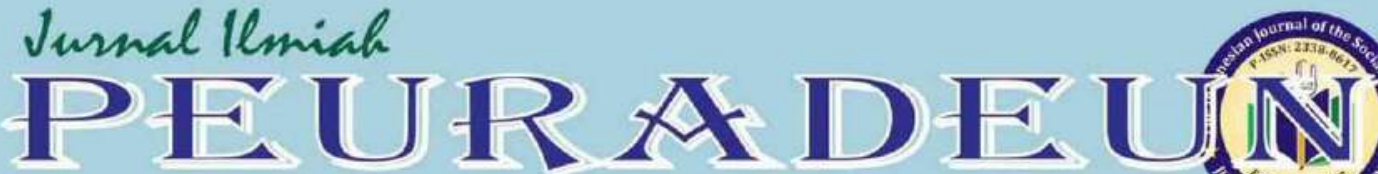

Vol. 8, No. 3, September 2020

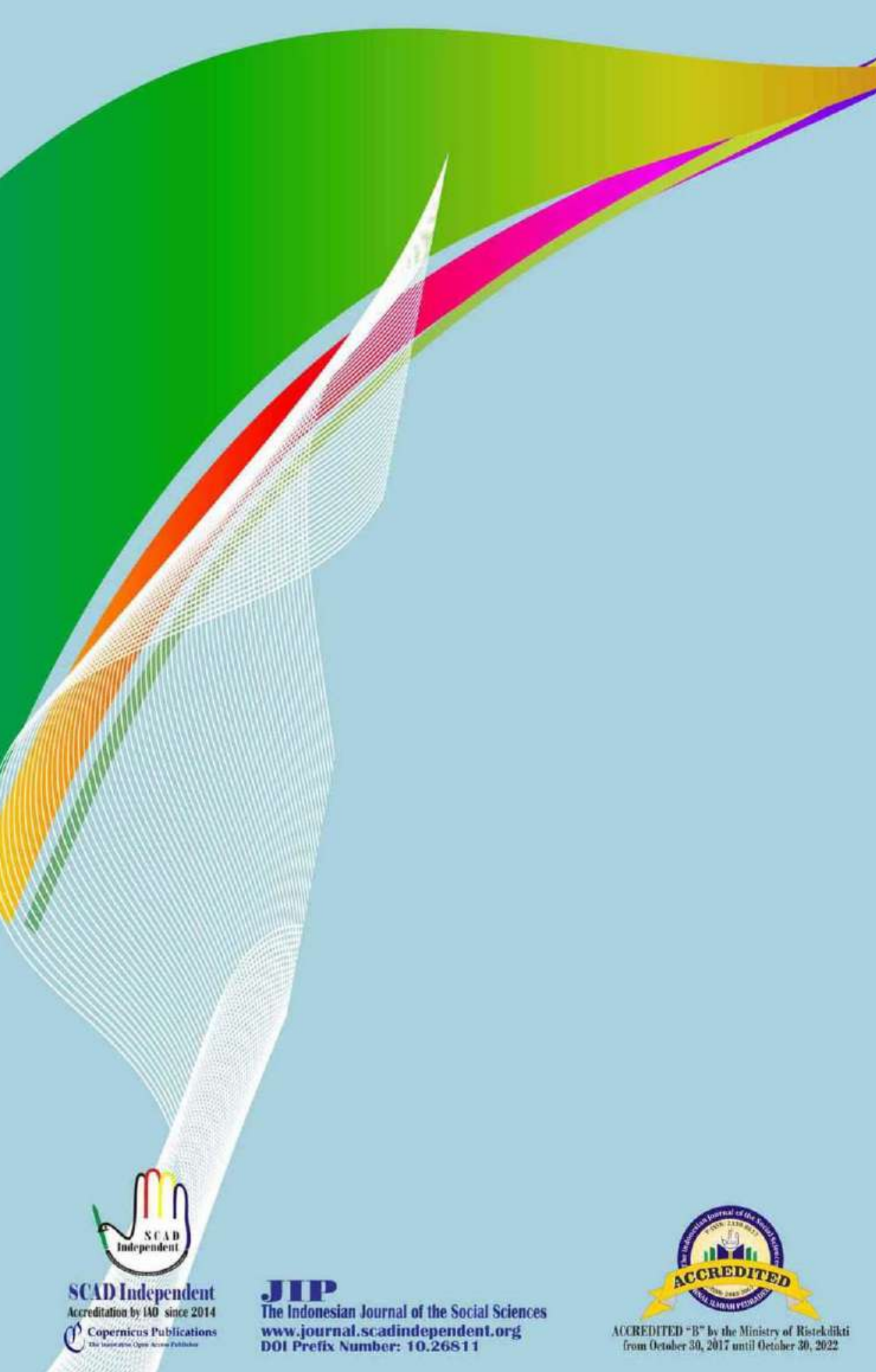

\section{Clarivate Analytics}

Emerging Sources Citation Index Web of Science ${ }^{\mathrm{TM}}$

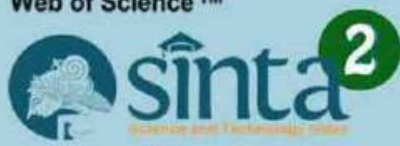

INDEX $\circledast$ COPERNICUS www.journal.scadindependent.org Dot Prefix Number: 10.2681 


\author{
JURNAL ILMIAH PEURADEUN \\ The Indanesian Journal of the Sacial Sciences \\ p-ISSN: 2338-8617/ e-ISSN: 2443-2067
}

www.journal.scadindependent.org

\author{
Vol. 8, No. 3, September 2020
}

Pages: 553-566

\title{
The Impact of Social Media on Adolescent Self-Concept: An Overview Based on Self Theory
}

\author{
Arri Handayani1; Sudargo²; Padmi Dhyah Yulianti ${ }^{3}$; Sukma Nur Ardini4 \\ 1,2,3,4 Universitas PGRI Semarang, Indonesia
}

\author{
Article in Jurnal Ilmiah Peuradeun \\ Available at : https://journal.scadindependent.org/index.php/jipeuradeun/article/view/512 \\ DOI $\quad$ : http://dx.doi.org/10.26811/peuradeun.v8i3.512
}

\section{How to Cite this Article}

APA : Handayani, A., Sudargo, S., Yulianti, P., \& Ardini, S. (2020). The Impact of Social Media on Adolescent Self-Concept: An Overview Based on Self Theory. Jurnal Ilmiah Peuradeun, 8(3), 553-566. doi:10.26811/peuradeun.v8i3.512

Others Visit : $\quad$ https://journal.scadindependent.org/index.php/jipeuradeun

Jurnal Ilmiah Peuradeun (JIP), the Indonesian Journal of the Social Sciences, is a leading peer-reviewed and openaccess journal, which publishes scholarly work, and specializes in the Social Sciences that emphasize contemporary Asian issues with an interdisciplinary and multidisciplinary approach. JIP is published by SCAD Independent and published 3 times of year (January, May, and September) with p-ISSN: 2338-8617 and e-ISSN: 2443-2067. Jurnal Ilmiah Peuradeun has become a CrossRef Member. Therefore, all articles published will have a unique DOI number. JIP has been accredited by the Ministry of Research Technology and Higher Education Republic of Indonesia (SK Dirjen PRP RistekDikti No. 48a/KPT/2017). This accreditation is valid from October 30, 2017 until October 30, 2022.

JIP published by SCAD Independent. All articles published in this journal are protected by copyright, licensed under a CC-BY-SA or an equivalent license as the optimal license for the publication, distribution, use, and reuse of scholarly works. Any views expressed in this publication are the views of the authors and not of the Editorial Board of JIP or SCAD Independent. JIP or SCAD Independent cannot be held responsible for views, opinions and written statements of authors or researchers published in this journal. The publisher shall not be liable for any loss, actions, claims, proceedings, demand, or costs or damages whatsoever or howsoever caused arising directly or indirectly in connection with or arising out of the use of the research material. Authors alone are responsible for the contents of their articles.

JIP indexed/included in Web of Science, MAS, Index Copernicus International, Sinta, Garuda, Moraref, Scilit, Sherpa/Romeo, Google Scholar, OAJI, PKP, Index, Crossref, BASE, ROAD, GIF, Advanced Science Index, JournalTOCs, ISI, SIS, ESJI, SSRN, ResearchGate, Mendeley and others. 


\title{
THE IMPACT OF SOCIAL MEDIA ON ADOLESCENT SELF-CONCEPT: AN OVERVIEW BASED ON SELF THEORY
}

\author{
Arri Handayanii ${ }^{1}$ Sudargo ${ }^{2}$; Padmi Dhyah Yulianti ${ }^{3}$; Sukma Nur Ardini ${ }^{4}$ \\ 1,2,3,4 Universitas PGRI Semarang, Indonesia \\ ${ }^{1}$ Contributor Email: arri.hdy@gmail.com
}

Received: Jan 24, 2020

Accepted: Jun 7, 2020

Published: Sep 30, 2020

Article Url: https://journal.scadindependent.org/index.php/jipeuradeun/article/view/512

\begin{abstract}
Adolescence is one of the hard phases in the development of human life. It happens because adolescents have to adjust themselves to the changes within their self, likewise to adapt to the society's demands which sometimes assume them as an adult. If the situation cannot be responded wisely, it will adversely affect adolescents especially in the digital era where social media is very popular and has a great influence on adolescents. Furthermore, if in the end, adolescents cannot show their true 'self' for the sake of getting a lot of followers, comments, and likes. This writing was supposed to analyze adolescents and social media especially the effect of social media on adolescents based on self-theory. The method used was the literature review which includes the source, as follows; research abstract, review, and journal. The analysis method was based on the analysis theory about self from Carl Roger. Self-theory was used when discussing adolescents and social media. The self develops through individual interaction with the surroundings. In this case, because of the demand to get a lot of followers, comments, and likes which cause the adolescents often did not show their true selves.
\end{abstract}

Keywords: Adolescents; Social Media; Self-Theory; Self-Concept 


\section{A. Introduction}

Adolescence is one of the hard phases in the development of human life. This condition happens because adolescents have to adjust themselves to the changes within their self, likewise to adapt to the society's demands which sometimes assume them as an adult. Adolescents are expected to be able to adapt, to account for their social behavior, and to meet society's requirements. Adolescents must adjust to people outside the family who may behave differently behavior from those in their families, including having to adjust to their relationships with the opposite sex (Handayani, 2019). Although there are many challenges in its development, adolescents must be able to do everything said.

It is not easy to become an adaptive adolescent, especially in the digital era. The conditions where all facilities can be carried out by technological developments. If this condition is not addressed wisely, it will destroy adolescents.

Along with technological developments, many adolescents are taking advantage of technological sophistication to show self through social media. Data from the Ministry of Communication and Information Indonesia reveals that internet users in Indonesia have reached 68 million people and 95 percent of them use the internet to access social media (Kominfo, 2013).

The self showed in social media often made by their own social identity separated from their true self. Based on Turner and Oakes (McKinley et al, 2004), social identity persists that a portion of one's selfconcept is dependent on the importance and relevance placed on the group membership(s) to which individual belongs. Furthermore, Kurniawati (2018) stated that the cyber world has become an adolescent's second world after their life in the real world. It makes adolescents have to change themself to fit in certain societies.

To get a lot of praise from the comments column and many likes that are considered as the highest achievement in using social media, making adolescents sometimes show fake identity that is not following their reality. This gap will make individuals develop self-concepts that tend 
to not suit their condition. When an adolescent uses social media, they can experience or show incongruence, which is a tendency to show a true or incomplete identity on social media. This is quite dangerous for the development of adolescents themselves. This form of incongruence occurs through various social media such as Facebook, Twitter, and Instagram.

Social media has two sides; good and bad. The good side is used to communicate, share, make friends, marketing online, or just to play games, while the negative side is when users are not able to manage the use of social media so it will cause addiction to social media and there is a tendency to show self that is not in accordance to reality.

Adolescents do not have a good understanding of smartphoneused. This condition was reflected when the writers did community service in Mukti Harjo Kidul Village, Semarang City. Some participants asked about the use of smartphones, including how to not intensively use a smartphone. Another thing is how do adolescents get interested in positive things in a smartphone?

The answer to these questions is self-control. Each individual who understands their own needs, also what they are looking for on a smartphone. Thus, what should be done is to focus on the main purpose and not to be tempted by other features in the smartphone (Handayani et al., 2019).

If there is no assistance from parents and is not addressed wisely in such conditions, there will be a bad impact on adolescents. A condition when social media is very popular and has a big influence on adolescents. Especially, if in the end, adolescents do not show their real selves to get many followers, comments, and likes. Even though technology development is addressed wisely, it will have a positive impact on adolescents. On the other hand, together with the stage of development that experience ambivalence between childhood and adulthood, adolescents will experience an identity crisis. The adolescents often are not confident with the changes of both physical and psychological in themselves. Therefore, adolescents will try to show who they are to show their existence. There will be no problem if what is shown to the world is indeed a real condition, but if what is shown is the adolescent's imagination. This condition will certainly bring many problems. 
Therefore, in this study, we will discuss how the relationship between adolescents and social media based on self-theory. The assumptions, that are used, are according to Roger (Cervon \& Pervin, 2011), self or self-concept symbolizes the pattern of regular and consistent perception. Furthermore, it is stated that self is a series of regular perceptions that individuals have. Even though the self changes, it always maintains, integrates, and organizes the quality of this pattern. Thus, the individual will try to behave according to the self.

However, because there are many demands for followers, comments, and likes, adolescents often do not show their real selves. Based on the background above, the writers are interested in conducting an analysis of adolescents with social media based on self-theory.

\section{B. Literature Review}

\section{Social Media}

Social media is a communication tool used by users in social processes (Mulawarman \& Nurfitri, 2017). In line with it, based on Boyd (Nasrullah, 2015) social media is a collection of software that allows individuals and communities to gather, share, communicate, and in certain cases collaborate or play with each other.

Based on the result of Mulawarman \& Nurfitri's research (2017), it is known that the latest issues related to the use of social media are selfie, cyberwar, user personalization, share culture, and online shopping. This condition certainly has positive and negative effects depending on how the user uses it.

Syaripudin, et al. (2010) suggested that the positive effect of social media for children and adolescents is they can learn to develop technical and social skills that are very much needed in the digital era like today. The individuals will learn to adjust, socialize with the public, and manage friendship networks. Through social media networking sites, children are easier to make friends with other people, although most of them have never been met directly.

Children and adolescents will be motivated to learn to develop themselves through friends found online. This condition is because they 
interact and receive feedback from each other. Social media sites also make children and adolescents more friendly, caring, empathetic, for example; giving attention in friends' birthday, commenting on photos, videos, and the status of their friends, maintaining a friendly relationship even though they cannot meet physically.

Furthermore, it is also stated by Syaripudin, et al (2010) that the negative effects of social media are children and adolescents being lazy learning to communicate in the real world. The level of understanding of the language becomes disturbed. If the children communicate too much in cyberspace, then the knowledge of the intricacies of communicating in real life, such as body language and tone of voice becomes reduced.

Social media sites will make children and adolescents more selfish. They become unaware of the environment around them because most of their time is spent on the internet. This can result in children becoming less empathetic in the real world. For children and adolescents, there are no spelling and grammar rules on social networking sites. Such conditions will make them increasingly difficult to distinguish between communicating on social networking sites and the real world. This certainly affects school writing skills in terms of spelling and grammar. Another condition, social media sites are fertile ground for predators to commit crimes. A person will never know whether an individual who is new to someone on the internet uses his true identity.

\section{Self Concept}

Papalia and Olds (1996) stated that self-concept is a comprehensive picture of one's abilities and traits. The self-concept owned by each individual will have a strong influence on the behavior of the individual. An introduction to self-concept for adolescents needs to be done because by introducing, adolescents will be able to understand their behavior.

If an adolescent describes, shows, and manifests his behavior as someone with a negative self-image, then this also relates to the adolescent's judgment about his self-image and vice versa. How an adolescent presents himself will depend on how their perception of himself. 
The factors that shape self-concept are parenting, peers, physical appearance, and the role of self-esteem (Saraswatia, Zulpahiyana, Arifah, 2015). While the concept of self has several components, such as spiritual self, material self, social self, and bodily self. The spiritual self is related to satisfaction with what has been done and not only on what one has. The material self consists of everything that is owned and is part of the self such as clothing. The social self is related to everything about other people. Meanwhile, the physical self is related to the physical condition of the individual with the case such as height, hair color (James in Killing and Killing, 2015).

Furthermore, Calhoun and Acocella (1990) stated that parents, friends, and society tell us how to define ourselves. Thus, the concept of self is not "given" but is a learning process that can be done by individuals through contact with the social environment and is formed through experience.

\section{Adolescent}

Together with the development of adolescents who are looking for an identity, there are also psychological changes in line with their physical changes. These conditions include frequent anxiety, awkwardness in relationships, as a result of physical changes. Adolescents often show the overacting to hide those feelings, explosive emotions, irritability, and easily offended to show that they are an adult. They also conduct experiments or always have the desire to try new things or that are generally done by adults (Handayani, 2019).

On the other hand, adolescents today are digital natives, a popular name for generations born after the 90s (Uswah, 2014), who have known electronic and digital media since they were born. The digital natives' generation fills their life with more use of computers, video games, digital music players, video calls, and various kinds of game equipment produced in the digital age.

This condition has an impact on not being able to escape these adolescents from the technology range in their daily lives. Starting from waking up to going to sleep again, the adolescents will always connect with technology. Individuals born in the span of the said year tend to 
understand technology, self-confidence ambition, prioritizing results, preferring to work in a group, trying to achieve a balance of work and personal life (Khera \& Malik, 2014).

Adolescents often work on tasks using gadgets that are not separated from their hands or sometimes using a headset that is still attached to their ear. They also often do the homework while watching YouTube videos or communicating through social media, both for chatting or discussing the subject matter being worked on.

Thus, when they hold gadgets, it is not always used for entertainment only but it can also be used for academic activities because even now some school tasks are also given via gadgets. Adolescents of this generation also tend to be open, so many activities are shared on social media. They will be happy and proud if they have many followers, likes, or comments.

According to Susana (2012), Indonesian adolescents today face multiple cultural norms. On one side, the reality life requires them to be independent, able to compete and to make choices on various things. On the other hand, society still does not provide adequate provisions for children to be able to live independently.

\section{Self-theory}

The main concept of Rogers' personality theory is self so that it can be said that self is the only true personality structure (Alwilson, 2005). According to Rogers (Cervone and Pervin, 2011), the self is a phenomenological experience. Phenomenological experience is one aspect of our experience in the world, one of which fulfills our conscious experience is the experience of ourselves. Besides, it is said that the self or self-concept symbolizes a regular and consistent pattern of perception. Besides, it is said that self is a series of regular perceptions that individuals have. Even though the self changes, it always maintains, integrates, and organizes the quality of this pattern. Thus, the individual will try to behave according to the self.

The same thing was stated by Alwilson (2005) that self or self-concept is a comprehensive and organized overall concept composed of characteristic perceptions of " $\mathrm{I}$ " or " $\mathrm{me}$ " (me as a subject or an object) and perception of the 
relationship in "I" or "me" with other people and various aspects of life, along with the values involved in that perception. The concept of self is describing people's conceptions of themselves, characteristics that they consider to be part of themselves. It also describes self-views concerning their various roles in life and interpersonal relationships.

Moreover, Roger stated that there are two different aspects of self; real self or actual self with ideal self. The real self is the real condition of an individual. Whereas, the ideal self is related to how self-concept will be built by individuals. The ideal self is related to the perception that will be built by the individual itself which includes perceptions and meanings that are potentially relevant to self and highly valued by individuals. An ideal self is a self-concept that individual desires to have.

Thus, the self itself is a comprehensive concept of a person which includes attitudes, feelings, and observations of someone about himself as well as what someone thinks about himself.

\section{Method}

This study used a literature review method to analyze the result of previous studies that are related to adolescents and social media especially based on an overview of self-theory. The literature used as a source including abstracts of research results, reviews, and journals.

A literature search was done to access e-journals including Google Scholar or to visit the library (library research). The keywords used to explore this study are adolescents, social media, self-concept, and selfidentity. The method of analysis is based on the self-theory analysis.

\section{Results and Discussion}

\section{The impact of media social to adolescents based on a self-theory}

The digital world with all opium provides all the convenience and pleasure. If we do not interpret technological developments wisely, we will harm children's development. Moreover, today's children are a digital 
generation or digital natives, who have known digital equipment from the beginning. Thus, they always do the activities with their digital devices.

When an adolescent uses social media, they can experience or show incongruence, which is a tendency to show a true or incomplete identity on social media. This is quite dangerous for the development of adolescents themselves. This form of incongruence occurs through various social media such as Facebook, Twitter, and Instagram.

The theory of self is used in discussing adolescents and social media. Based on Roger (Cervon \& Pervin, 2011), self or self-concept symbolizes regular and consistent patterns of perception. Furthermore, it is stated that self is a series of regular perceptions that individuals have. Even though the self changes, it always maintains, integrates, and organizes the quality of this pattern. Thus, the individual will try to behave according to the self.

Then, selfie seems to be an important and interesting thing for adolescents through photo, writing, or video facilities, and even location sharing. This condition is increasingly popular among adolescents with the support of various applications such as adobe photoshop, camera 360, plastic surgery, dan beauty plus magical camera, etc (Nastiti \& Purworini, 2018).

In line with other previous studies, Ayun's research (2015) resulted that in using Facebook, individuals indirectly shape their self-identity through three images that are personal orientation, individual values, and self-expression. The individual values which have been shown illustrate the concept of self.

The experience of adolescents who are incongruent or not the following self-concept will be a threat and manifested in the form of anxiety. Individuals who do not have incongruence will influence the psychological adjustment process and affect their mental health (Hidayat, 2011).

This is following the results of Mulawarman \& Nurfitri's research (2017) that a successful selfie is marked by a lot of praises, thumbs up, or likes (Facebook's features). If so, an individual is satisfied and more encouraged to take more selfies and upload it on social media. However, if the condition of an individual is ignored and not respected by the social 
environment, it will trigger the desire to not re-upload or keep taking selfies, but with certain evaluations. The popularity of a photo will have an impact on self-presentation and self-confidence (Nastiti \& Purworini, 2018).

These children have not fully understood that identity, photos, or events existed in cyberspace may not true. All of them may be just camouflage that aims to attract many followers. The condition of adolescents who do not show their true selves may not be able to accept themselves as they are. According to Rahma (2016), young women tend to make selfie activities as a correction of imperfect facial and physical forms. They are not only anxious about physical appearance but also emotional self-acceptance which is also not stable.

Self-acceptance indicates an agreement between an individual and himself to accept, appreciate, respect, and motivate his situation under any circumstances (Santrock, 2008). Meanwhile, according to Rahma (2006) self-acceptance is a feeling of love and happiness towards one's self in any case. If this condition continues, the individual becomes not recognizing himself and tends to want to be someone else he wishes. A lot of risks will occur in this condition; physical, psychological, and material.

Social media is a tool to show a picture or self-image of adolescents. As long as what is shown is a real picture of adolescents, there will not be a significant problem. However, when what is showed is very different from the real conditions, and especially only as a positive image grower for adolescents, this condition will be dangerous and cause many problems. In general, adolescents expect others to see what they want. Thus, adolescents eventually become ignorant of themselves. Many things are not under the actual conditions to get recognition from others about a positive self-image. In a long period, this condition will interfere with adolescents' mental health.

\section{E. Conclusion}

Adolescents are one of the hard phases in the development of human life. It happens because adolescents have to adjust themselves to the changes within their self, likewise to adapt to the society's demands 
which sometimes assume them as an adult. If the situation cannot be responded wisely, it will adversely affect adolescents especially in the digital era where social media is very popular and has a great influence on adolescents. Furthermore, if in the end, adolescents can not show their true selves for the sake of getting a lot of followers, comments, and likes.

On the other hand, the self develops through the interaction of individuals with their environment. Individuals should behave according to their real conditions. However, due to the desire of showing themselves more, adolescents do not show their true selves. Eventually, adolescents tend to not accept, do not recognize themselves and in the end, tend to want to be someone else they expected. A lot of risks will occur in this condition; physical, psychological, and material. Therefore, parental supervision is needed especially in the use of media social so that adolescents are more careful in showing themselves. The adolescents need to filter out what is needed to be conveyed in social media and what is supposed to be personal consumption. This is because of what is revealed by someone who reflects his personality. Another condition is because social media is a fertile ground for predators to commit crimes. Someone will never know whether the individuals, who are new on the internet, use their true identity.

\section{Bibliography}

Alwisol. (2005). Psikologi Kepribadian. Malang: UMM Press.

Ayun, P.Q. (2015). Fenomena Remaja Menggunakan Media Sosial dalam Membentuk Identitas. Channel, 3, 2, 1-16.

Cervone, D. \& Pervin, L.A. (2011). Kepribadian: Teori dan Penelitian. Translated by Aliya Tusyani, Evelyn Ridha Manulu, Lala Septiani Sembiring, Petty Gina Gayatri, Putri Nurdina Sofyan. Jakarta: Salemba Humanika.

Fadli, F., Prestwich, A., \& Sykes-Muskett, B. (2018). Assessing Mediating Effect of Motivation Types on Competition Intervention For Physically Inactive Adults. Jurnal Ilmiah Peuradeun, 6(1), 1-16. doi:10.26811/peuradeun.v6i1.156

Handayani, A, Sudargo, Yulianti, P.D., Ardini, S.N., Setiawan, D.F. (2019). Pembinaan Kampung KB di Kelurahan Muktiharjo Kidul Kota 
Semarang. Laporan Pengabdian Kepada Masyarakat. Semarang: Universitas PGRI Semarang. Unpublished.

Handayani, A. (2019). How to Raise Great Family, Mengasuh Anak Penuh Kesadaran. Jakarta: Grasindo.

Hidayat, D.R. (2011). Psikologi Kepribadian dan Konseling. Bogor: Ghalia Indonesia.

Hughes, K., \& Batten, L. (2016). The Development of Social and Moral Responsibility in Terms of Respect for the Rights of Others. Jurnal Ilmiah Peuradeun, 4(2), 147-160. doi:10.26811/peuradeun.v4i2.93

Khera, S.N \& Malik, S. (2014). Life Priorities and Work Preferences of Generation Y: An Exploratory Analysis in Indian Context. Jindal Journal of Business Research 3 (1\&2) 63-76.

Kiling, B.N., \& Kiling, I.Y. (2018). Tinjauan Konsep Diri dan Dimensinya pada Anak dalam Masa Anak - Anak Akhir. Jurnal Psikologi Pendidikan \& Konseling. http://ojs.unm.ac.id/index.php/JPPK Volume 1 Nomor 2 Desember 2015. Hal 116-124. p-ISSN: 2443-2202 e-ISSN: 2477-2518.

Kominfo: Pengguna Internet di Indonesia 63 Juta Orang. 2013. https://kominfo.go.id/index.php/content/detail/3415/Kominfo+\%3A +Pengguna+Internet+di+Indonesia+63+Juta+Orang/0/berita_satker.

Accessed at 1 Desember 2019.

Kurniawati, D. (2018). The Impact of Teenager Dependency on Social Media and the Anticipate Effort. International Journal of Scientific $\mathcal{E}$ Technology Research, 7, 8, 28-30. ISSN 2277-8616.

McKinley et al. (2014). Social Identity Theory as a Framework for Understanding the Effect of Exposure to Positive Media Image of Self and Other on Intergroup Outcomes. International Journal of Communication, 8, 1049-1068.

Mulawarman, Nurfitri, A.D. (2017). Perilaku Pengguna Media Sosial beserta Implikasinya Ditinjau dari Perspektif Psikologi Sosial Terapan. Buletin Psikologi ISSN 0854-7106 (Print) 2017, 25 1, 36 - 44 ISSN 2528-5858 (Online) DOI: 0.22146/ buletinpsikologi.22759.

Nasrullah, R. (2015). Media Sosial; Perspektif Komunikasi, Budaya, dan Sosioteknologi. Bandung : Simbiosa Rekatama Media.

Nastiti, A.D.S., \& Purworini, D. (2018). Pembentukan Harga Diri: Analisis Presentasi Diri Pelajar SMA di Media Sosial. Jurnal Komunikasi 10, 1, 33 - 47 ISSN 2085- 1979, E-ISSN 2528-2727. 
Papalia. D.E \& S.W. Olds. (1993). A Child's World, Infancy through Adolescence. USA: Mc. Graw-Hill, Inc.

Rahma, R.Y. (2016). Fenomena Self Potrait Di Kalangan Remaja. Jurnal Visi Komunikasi 15, 01, 127-142.

Saraswatia, G.K., Zulpahiyana, \& Arifah, S. (2015). Faktor-Faktor yang Mempengaruhi Konsep Diri Remaja di SMPN 13 Yogyakarta. Jurnal Ners dan Kebidanan Indonesia. ISSN 2354-7642.

Sarwono, S.W. \& Eko, A.M. (2009). Psikologi Sosial. Jakarta: Salemba Medika.

Susana, T. (2012). Kesetiaan pada Panggilan di Era Digital. Jurnal Orientasi Baru. 21, 1, 55-78.

Syaripudin, A., Aminudin, A., Taufik, A., Ningrum, D.W., Ifransah, M., Aryanto, Y. (2010). Internet Sehat. 3rd Ed. Pedoman Berinternet yang Aman, Nyaman, dan Bertanggungjawab. http://www.internetsehat.org. Accessed at 23 May 2017

Turner, J. C., \& Oaks, P.J. (1986). The Significance of the Social Identity Concept for Social Psychology with Reference to Individualism, Interactionism, and Social Influence. British Journal of Social Psychology, 25, 237-252.

Uswah, L.K. (2014). Konsumsi Gadget Siswa Sekolah Dasar Muhammadiyah Kota Yogyakarta. Berkala Ilmu Perpustakaan dan Informasi, 10, 2, 24-32. 
p-ISSN: 2338-8617 